\section{Does higher owner participation increase conflicts over common land? An analysis of communal forests in Galicia (Spain)}

\author{
Manuel Francisco Marey-Pérez, Emilio Díaz-Varela, \\ Alexia Calvo-González
}

Communal forests or Montes Vecinales en Mano Común (MVMC) are a type of private collective land in Galicia (northwest Spain) representing approximately one-third of its forest land. There has been a series of changes in MVMC ownership and management throughout the $20^{\text {th }}$ century. Uncertainty about ownership, changes in population and the presence of the Forestry Administration has caused deficiencies in management and increased conflict. This paper analysed MVMC management in 1731 parishes in Galicia. The digital records of local and regional newspapers were used to compile a database of 2734 news reports related to MVMC issues. The results of hypothesis testing and spatial analysis showed that population, agricultural activity and land use affected management and conflict rates. This paper discusses how active management and conflict are complementary models, and how the presence or absence of one or the other is a determining factor in the situation of each parish. It concludes that it is necessary to implement management models and strategies to minimize conflict and increase active management for sustainable forest development in the region.

Keywords: Commonly-owned Private Property, Communal Forests, Media, Social Participation, Management Models

\section{Introduction}

In a modern sense, public participation in devising forest management is voluntary. Within public participation processes, people, individually or in organized groups, can exchange information, express opinions and articulate interests with the aim of influencing the final result in decision making (ILO 2000, Aasetre 2006, Atmis et al. 2007). It is both an opportunity and a need for today's society, as it is a useful tool to avoid conflicts, share information and encourage good relations with the planning team (Hellström 2001, Kangas \& Store 2003, Santos et al. 2006, Janse \& Konijnendijk 2007, Hiltunen et al. 2009, Cantiani 2012). Public participation contributes to democratization through the reinforcement of transparency in decision making: it increases plurality of aims, en-

courages mutual learning and increases the awareness of collective responsibility for natural resource management questions (Elsasser 2002, Kangas et al. 2010, Lennox et al. 2011).

According to Ostrom \& Nagendra (2006), sustainable governance of natural resources is a challenging task, in which "major debates occur over what types of policy interventions best protect forests, with choices of property and land tenure systems being central issues" and natural resource management can be approached from different views. There are regional differences in practical approaches to biodiversity conflict management because the social, political and economic characteristics of a culture influence the type of conflicts and the response to them (Hellström 2001). In this context, con-

Escola Politécnica Superior, Dept. Agroforestry Engineering, University of Santiago de Compostela, E-27002 Lugo (Spain)

@ Manuel Francisco Marey-Pérez (manuel.marey@usc.es)

Received: Jun 27, 2013 - Final Acceptance: Oct 16, 2014

Citation: Marey-Pérez MF, Díaz-Varela E, Calvo-González A, 2014. Does higher owner participation increase conflicts over common land? An analysis of communal forests in Galicia (Spain). iForest 8: 533-543 [online 2014-12-01] URL: http://www.sisef.it/iforest/ contents/?id=ifor1060-008

Communicated by: Raffaele Lafortezza flicts are confrontations between opposing values and objectives of the stakeholders in the sustainable management of natural resources (Bojórquez-Tapia et al. 2004), often caused by different perceptions of the initial situation of the resources discussed (Gritten et al. 2009). Following Skutsch (2000), conflicts over biodiversity should be regarded as inherent in social participation, reinforcing the ideas of Hellström (2001), which are seen as an important part of the decisionmaking process on how to use the natural resources.

Conflicts usually have negative effects on forest management (Druckman 2005). However, the key to understanding and to the new social demands in forest areas (Hellström 2001) lies in the nature of conflicts. Many authors have analyzed conflicts in forest areas (Elands et al. 2004, Maskey et al. 2006, Djamhuri 2008, Schlueter 2008). White et al. (2009) developed a new and innovative framework aimed at improving the conceptual understanding of biodiversity conflicts. This method is based on the analysis of ecological, economic and social factors that affect the behavior of the biodiversity actors responsible for the conflict. This system is useful in developing strategic models to improve the understanding of general conflict dynamics.

The aim of the study is to classify in groups the parishes with communal forest land of the Montes Vecinales en Mano Común (MVMC), to analyze the different management levels and models, and how these influence conflict appearance. Specifically we test the hypothesis that an increase in public participation implies a greater level of conflict in the management of these communal lands. If such a difference exists, what variables associated with population, property and land-use management explain the difference.

\section{Current State}

Common land is that where property rights are exerted collectively, be it by a community or by one person, leaving other people with certain rights to the property of land (Brett 2005). Such rights are determined by internal rules transmitted by tradition inside the community. It has played a key role in the economic development of rural areas (Glück 2000, Short 2000, Maskey et al. 2006, Pagdee et al. 2006) regardless of its function and use.

Mei Szen \& Sovacool (2013) indicated that the criteria of efficiency, equity, sustainability and compatibility should be utilized to manage conflicts in land use. In some areas managed by the Forestry Administration in Galicia (Spain), a greater number of fires occurred as a result of conflicts (Gómez-Vázquez et al. 2009). The management of com- 


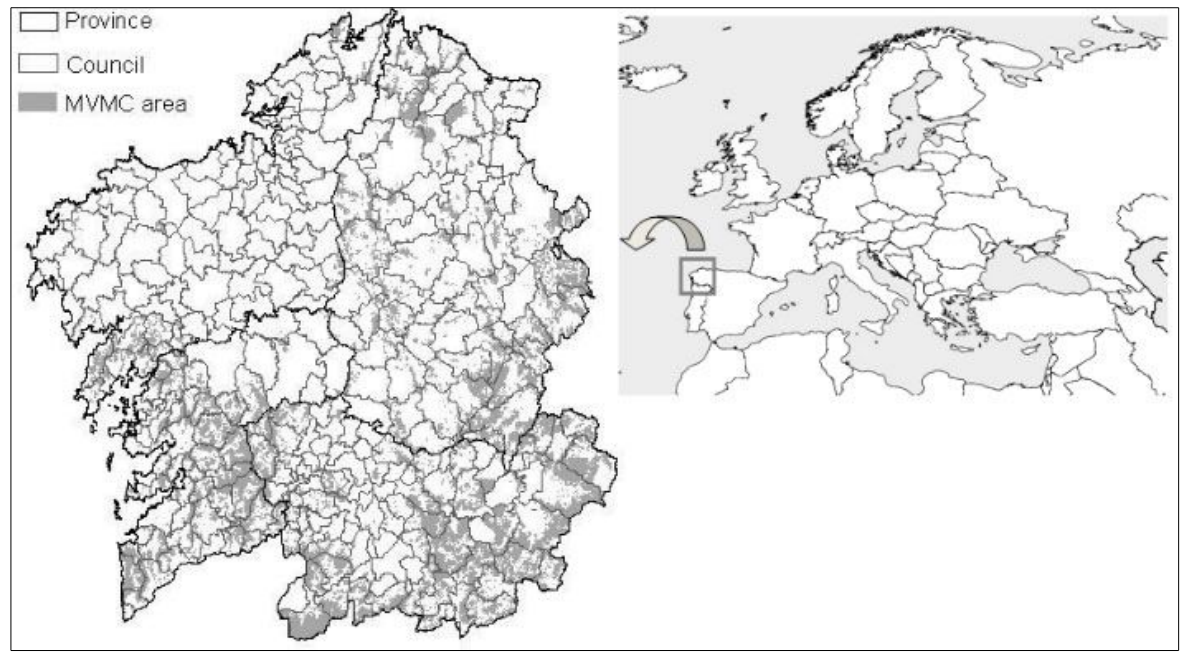

Fig. 1 - Geographic distribution of MVMC (communal forests) in Galicia (NW Spain).

munal forests, as a common land where ownership is private but collective, implies the participation of the involved community in the use of land and organization of space. Dietz et al. (2003) indicated the risk of degradation from overuse that communal natural resources can suffer due to being managed by institutions that do not fulfill the aims for which they were created. Alberich (2002) saw social participation as a set of activities, processes and techniques by which people involved in public affairs influence forest management. Penker (2009) defined participation as the ability of the local population to decide and develop their own rules and structures, which are based on "structural variables [that] affect the core relationships of reputation, trust, and reciprocity" (Ostrom 2010). Nevertheless, the complexity of the previous processes of spatial concentration, association and social participation may lead to passive attitudes towards forest management (Pinto-Correia 2000, Schlueter 2008), or situations of conflict (Bogale et al. 2006 , De Jong et al. 2006, Matta \& Alavalapati 2006, Brehm 2007, Siiskonen 2007).

Among the different methods available to detect and characterize attitudes among the population, the analysis of mass media allows to determine the social impact of natural resource management from a global and inclusive perspective, without incurring high survey costs. In fact, newspapers are the main source of public information concerning environmental issues (McCallum et al. 1991). Therefore, news and media have been used in different research works and studies in the last 15 years. News from different media were analyzed to assess the evolution of values related to forests for different social groups (Xu \& Bengston 1997). Newspaper coverage of the environmental impact of a project and the contribution of the type of news and images to the change in readers' opinion has also been assessed (Ohkura
2003). Similarly, Wakefield \& Elliott (2003) analyzed how local newspapers informed concerning environmental risks. More recently, Hovardas \& Korfiatis (2008) studied how the press tackles the management of a forest reservation in Greece.

More specifically, the way in which media reflect forest communities is an indicator of their level of management and organization (Aasetre 2006). Yasmi et al. (2006) used a compilation of articles published in international peer-reviewed journals to organize agricultural and forestry conflicts into a hierarchy of categories. This is particularly useful in the analysis and assessment of the social relevance of forest communities in the study area and of the interactions of social relevance with economic and environmental issues (Gómez-Vázquez et al. 2009). White et al. (2009) considered that the analysis of mass media could be an interesting indicator to address the issue of conflict in natural resource management. Therefore, the analysis of communities' attitudes towards forest management could help in characterizing their degree of involvement, allowing identification of passive behavior and constituting the basis for development of dynamization strategies of the management.

\section{Materials and methods}

\section{Location}

Galicia is a province in northwest Spain characterized by a high relative percentage of its total forest area, which represents over $60 \%$ of its surface area and accounts for $11 \%$ of the total forest area in Spain. More than two-thirds of the Galician forest area is privately owned, and $30 \%$ are communal forests (MVMC), a characteristic form of communal land in Galicia (Balboa López et al. 2006, Fernández et al. 2006, Marey-Pérez et al. 2006). MVMC shares characteristics with other traditional European commons that survived the liberalization wave of the $19^{\text {th }}$ century and have since faced a number of challenges, but still maintain some of their traditional significance. It is important to note that new uses have been found in terms of provision of ecological, leisure and natural services (De Moor \& Bravo 2008).

This type of land is collectively and privately owned by rural communities made up of groups of neighbors who live in a parish and who carry out economic activities there. The average size of communal forests is 230 ha, greatly exceeding the average size of parcels belonging to individual private owners, 1.5-2 ha/owner (Marey-Pérez \& Rodríguez-Vicente 2008, Marey-Pérez et al. 2010). Fig. 1 shows the distribution of Galician MVMC.

Independently of the different theories about their origin, Galician MVMC are shared by a group of people according to agreed rules, as are other forest communities in the European context (Merlo 1995, Glück 2000). In Galicia, their ownership has fallen to neighbors surrounding one or more villages, usually parishes, where the legal regime does not establish different quotas among co-owners - the place of residence or neighborhood determines access, which is egalitarian and free for neighbors and it is not possible to inherit or sell the use right (Marey-Pérez 2003). The parish population engages in collective actions to manage their forest lands sustainably as complementary activities for the family economy without any external governing authority. All individuals who live in a parish with MVMC are communal owners (comuneros) and hence also enjoy right of use, despite there being no duty to participate in joint forest management.

The complementary activities on MVMC have been linked with agrarian activities, where these lands were a significant support in the traditional agrarian system (Bouhier 1979). But some forest functions, such as timber production, have not been of great relevance in Galician forests. The sparsely wooded lands, compensated only by natural regeneration, were destined to produce firewood and forest products for households, ensuring land upkeep including forms of association between agriculture and forestry.

Since the 1950s, significant number of the rural population have moved to urban areas, causing the abandonment of extensive agrarian areas and changing the agricultural landscape to scrub and forest. In the middle of the $20^{\text {th }}$ century, the Spanish State assumed the regulation of this type of property, assimilating it into public participation mainly at the municipal level but also state. The government began to actively work on MVMC administration through the organization Patrimonio Forestal del Estado (PFE) and by means of agreements (named consor- 
tia) giving legal responsibility to the MVMC councils. Communal forestlands were reoriented towards forest production by means of their reforestation with fast-growing species (Groome 1990), consolidating an economic business that tried to change the national deficit in forest production and make the country self-sufficient in forestry.

With these socioeconomic patterns, the traditional uses of communal lands changed and the Galician rural system became unbalanced. Due to the alteration of the traditional modus vivendi and the radical changes in rural landscapes, conflicting interests arose between economic development (administration) and traditional users (the neighborhood - O'Leary et al. 2000).

In 1968, with the State promulgation of the specific MVMC Law 52/68, the neighbors' communal property began to be considered indivisible, inalienable, imprescriptible and free of tributes, establishing the special treatment of Galician communal forests. Since the 1980s, as the Autonomous regions had the authority the administrative organization, the Galician Government became responsible for legislating and negotiating these properties in a subsidiary way, considering a specific Galician Law (no. 13/89) which defines the MVMC as: “...with independence of their origin, of their productive possibilities, of their current use and of their agrarian vocation, they belong to local groups in their quality of social groups and not as administrative entities, and can use commonly as a neighbors' regime".

At present, and in the immediate future, a series of challenges and opportunities face the MVMC. Among the former, forest fires are a prominent source of conflict (Chas Amil 2007, Fernandes 2008), tied to (and worsened by) ineffective management (Leiceaga et al. 2006) thus rendering the communal forest underused or directly abandoned. In low dynamic areas the opportunities are related to the potential of multifunctional use of forest land in to diversify income sources and generate new opportunities for economic and social development (Leiceaga et al. 2006).

\section{Data collection}

Digital mass media have been widely available in the study area since 2002. We searched for, classified and selected all news related to Galician forest communities that appeared in online newspapers with information about conflicts in MVMC to conduct a census between 30 June 2002 and March 31 2008. We also collected and analyzed all newspaper reports related to MVMC found in the digital libraries of national newspapers with a regional edition for Galicia (2), regional newspapers (1) or provincial and local newspapers (15). The readership of these newspapers accounts for $85 \%$ of the
1126000 people who daily read the online or print editions of Galician newspapers (AIMC 2009), and accounts for $40.2 \%$ of the total population of the region.

The data sources used have some limitations: geographical biases, since the media coverage is not uniform in the whole territory; and there are no data sources of the same nature to contrast information. Bengston \& Fan (1999) reached a similar conclusion: "As more small community newspapers become available online in the future, it will be possible to calculate separate conflict indexes for each region or even each state".

Additional data on land-use structure and socioeconomic variables were also analyzed (Niskanen \& Lin 2001). The National Statistics Institute (Instituto Nacional de Estadistica - INE 2008) provided the information on social and economic development (e.g., population density, structure and occupation). The Forest Map of Spain developed by the Spanish Ministry of the Environment, provided land-use data (e.g., wooded and non-wooded land area, agricultural land area or idle land). A census of Galician forest communities provided data on the population nucleus, parish, municipality and province to which each forest community belongs. All this information was merged and homogenized into a unique database, taking care that geographical references and quantitative units were compatible and comparable among sources.

Finally, we reviewed other research and descriptive studies (Díaz Fuentes 1999, Prada et al. 2001, Soliño 2003, Balboa López et al. 2006) to verify that the source of information used in our research completed the information provided by similar sources, thus sessing the significance of its contribution.

\section{Data processing}

News articles about conflicts were classified according to two criteria (Susskind \& Cruikshank 1987, Niemelä et al. 2005, Barli et al. 2006): (i) the nature of the conflict, whether social, economic or environmental (Owen et al. 2000); and (ii) the source or agent of the conflict, which could be intervalidating reliability of the source and as-

nal, i.e., within the community of owners (Brehm 2007) or external, i.e., with other forest communities (De Jong et al. 2006), enterprises, government organisations (Reed 2007) or NGOs.

Because many conflicts could be assigned to more than one category, conflicts were reclassified and grouped into six types (Fig. 2). Such a restructuring allowed for a better analysis and understanding of conflict classification.

Finally, newspaper reports were grouped into two categories: those related to social participation and to conflicts. Each category was in turn grouped into three sections. A database was created to classify the newspaper reports into different groups: (i) social issues (participation in the community, training and employment, conflicts, cultural activities and membership in an association or cooperative); (ii) environmental issues (forest fires, site contamination, degradation of natural resources, promotion of good management practices, fines and sanctions for poor environmental practices); and (iii) economic issues (public subsidies, traditional and innovative production activities, management reports, resource concessions and agreements)

\section{Statistical analysis}

A preliminary analysis was carried out on the variables analyzed in order to describe their central tendency and dispersion. Given that the socioeconomic variables involved generally show non-normal distributions, their departure from normality was tested by the Kolmógorov-Smirnov test (K-S test).

Analysis of variance (ANOVA) was carried out to test for significant differences among the hypotheses tested (Rice 1995, Hickey et al. 2007, Gómez-Vázquez et al. 2009, Wallgren et al. 2009). Equality of variances was verified using the Levene's test $(\alpha=0.05)$. Post-hoc tests (Miserendino \& Masi 2010) were used for the detection of significant differences among groups. The Scheffé test (Chambers \& Trevor 1992) was used to regroup ordinal variables into homogeneous subgroups based on similar values of the study variables.

\begin{tabular}{|c|c|c|c|c|c|}
\hline & & \multicolumn{4}{|c|}{ Nature } \\
\hline Class & Agent & social & & economic & environmental \\
\hline \multicolumn{2}{|l|}{ Internal } & 21 & 82 & & \\
\hline \multirow{4}{*}{ External } & Administration & 421 & 181 & & 445 \\
\hline & Enterprise & & 229 & & 209 \\
\hline & Other community & 121 & 98 & & \\
\hline & ONGs & 49 & 22 & & 38 \\
\hline
\end{tabular}

Fig. 2 - Classification of the studied conflicts based on several criteria described in "Mate rials and Methods". 


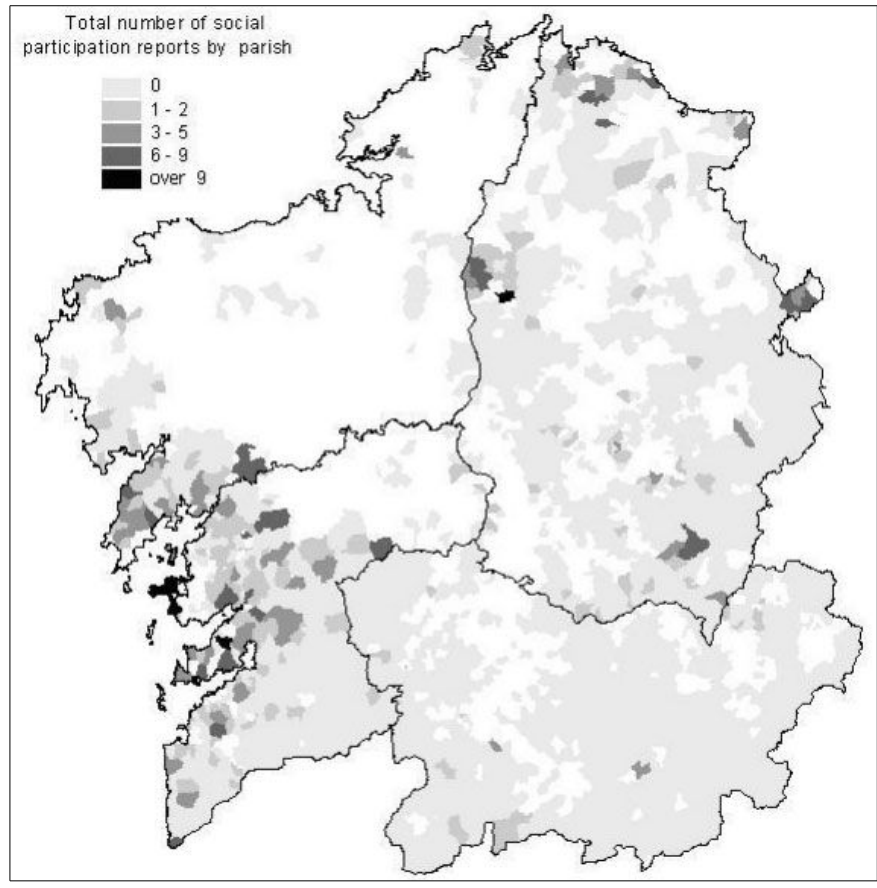

Fig. 3 - Geographical distribution of the analyzed social participation reports by parish.

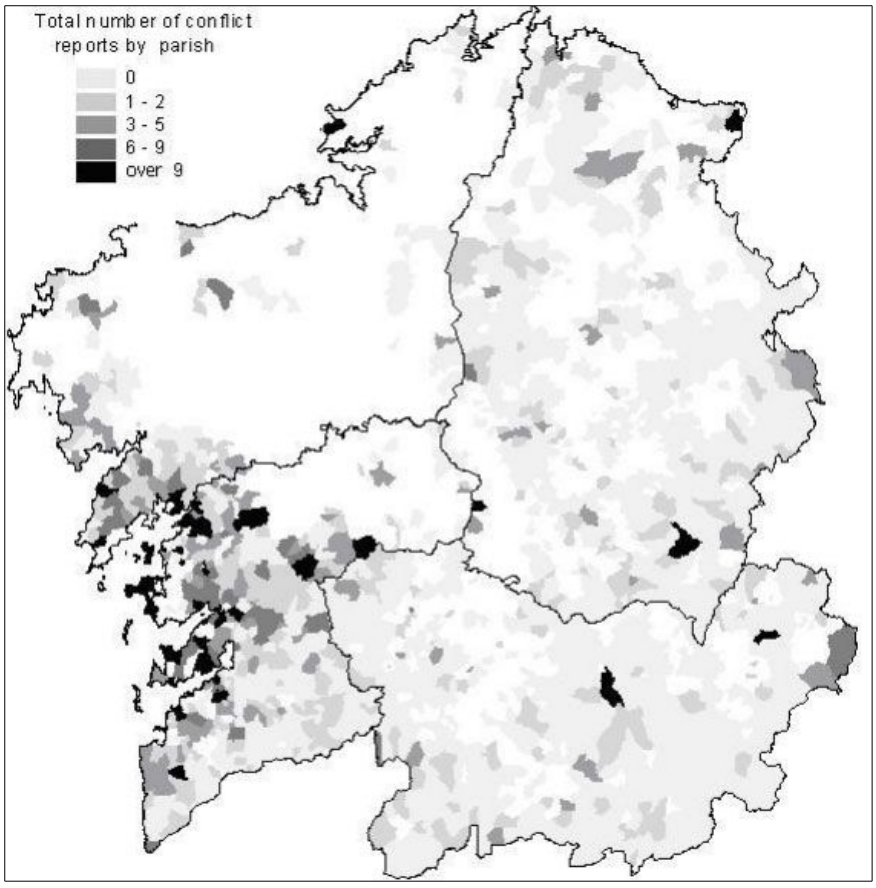

Fig. 4 - Geographical distribution of the analyzed conflict reports by parish.
All statistical analyses were conducted by the use of the software package $\mathrm{R}$ version 2.5.2 (R Development Core Team 2008). A free Geographic Information System software (GvSIG 2010) was used for spatial representation of the results of the statistical analysis, with the aim of detecting changes in the spatial distribution of news items (Carver et al. 2006).

\section{Results}

Galicia comprises 3793 parishes, 1731 of which have some forest community and ac- count for $45.6 \%$ of the total. We processed and counted all the news related to Galician parishes published in local, provincial and regional newspapers between June 30, 2002 and March 31, 2008. Overall, 2734 reports were compiled, concerning a total of $741 \mathrm{pa}-$ rishes, or $42.8 \%$ of all parishes with MVMC. The maximum number of reports per parish related to participation was 25 , while the maximum number of those related to conflicts was 42 .

Fig. 3 and Fig. 4 show the geographic distribution and abundance of the reports in-

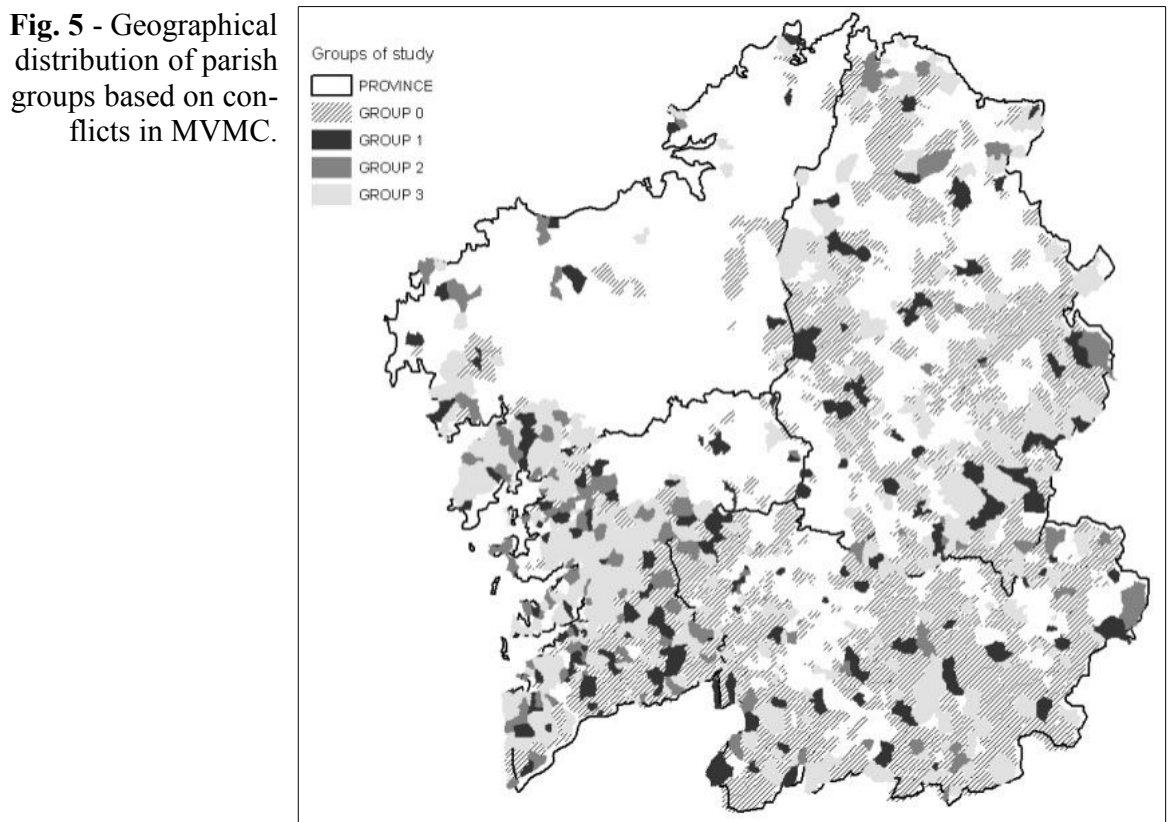

ferred from the news analyzed. The maps reveal a strong concentration of conflicts in the southwest of the region, but hardly any conflicts in the northwest. Spatial patterns were similar for all the types of conflicts considered.

Results of the classification of parishes into the aforementioned categories are reported in Tab. 1. The largest group was called GROUP 0 and comprised 990 parishes (57.2 $\%$ of the total). These parishes were characterized by a lack of management activity throughout the study period. The remaining 741 parishes $(42.8 \%)$ were divided into three groups, according to the news items on management and conflict. GROUP 1 included those parishes in which over two-thirds of the news items were about conflicts. In GROUP 2, there was a balance between news items about conflicts and news items on property management (participation). Finally, GROUP 3 included those parishes for which less than one-third of the news items were conflict related. As for the geographical distribution of such groups in Galicia, GROUP 0 comprised the south and southeast of the region (Fig. 5). GROUP 1 was spread over the whole territory, while GROUP 2 and GROUP 3 were along the west coast and, to a lesser extent, in the northwest.

We tested the hypothesis ANOVA that conflict appearance in the different groups (dependent variable) of parishes studied might be affected by several socioeconomic and land-use related factors (independent variables). The list of variables used in the 
ANOVA is reported in Tab. 2, along with the results of the goodness-of-fit to normality of their distribution. As expected, most variables showed a significant departure from the normal distribution after the Kolmogorov-Smirnov test. However, given the large dataset analyzed (see Tab. 1), this did not impair the results of the ANOVA carried out, according to the central limit theory (Rice 1995). Also, equality of variances for all the variables included in this study was confirmed by the Levene's test ( $p>0.05$ ).

Results of the ANOVA carried out are reported in Tab. 3. Significant differences among groups of parishes were found for seven out of 11 variables $(p<0.05)$, while mean values of only four variables showed no differences among groups $\left(\mathrm{PO}_{\mathrm{D}}: \mathrm{p}=\right.$ $0.632 ; \mathrm{PO}_{65}: \mathrm{p}=0.083 ; \mathrm{AG}: \mathrm{p}=0.158$; $\mathrm{EV}_{1960-2006}: \mathrm{p}=0.068$ ).

To detect possible sub-grouping within the parish groups, the seven variables showing significant differences after ANOVA were further investigated. The results of the Scheffe's test for the comparison among group means of the above variables are listed in Tab. 4 according to the variable type (population, agricultural activity and land use). Significant differences in the mean values of the variable $\mathrm{PO}_{2006}$ (population) were detected between parish groups GROUP 1 and GROUP 2, as well as between GROUP 2 and GROUP 3, suggesting the existence of two different subgroups. Similar results were obtained using the variable "Agricultural activity" $\left(\mathrm{OW}_{\mathrm{AG}}\right)$. In the case of surface area and land use, GROUP 1 and GROUP 3 showed significant differences for the variable $\mathrm{NO}_{\text {wood }}$ (Non-woodland forest area, \%), while no differences were found between GROUP 2 and the other two parish groups. Similar results were obtained using the FO FAST, (Forest area under fast-growing species, $\%$ ), FO (Forest area, \%) and $\mathrm{FO}_{\text {sLow }}$ (Forest area under slow-growing species, \%). Contrastingly, no significant differences among group means were detected for the variable $\mathrm{FO}_{\text {wood }}$ (Forest wood area, \%), indicating that the parish groups considered were homogeneous as for this parameter.

\section{Discussion}

As established by White et al. (2009), media analysis allow the differentiation of parishes with MVMC in relation to the importance of social conflict. The most commonly-used technique for differentiating between social groups is the survey (Barli et al. 2006, Marey-Pérez \& Rodríguez-Vicente 2008). However, the methodology used in this study has three major advantages over surveys: (1) the study can be carried out on a greater scale; (2) obtaining information is cheaper; and (3) the value of the results is different, as it is not based on the participants' opinion. As highlighted by Meitner et al. (2005), it is
Tab. 1 - Classification of parishes in different study groups based on the importance of conflicts out of the total number of news items.

\begin{tabular}{llrrrr}
\hline Group & Criteria used & Freq. & Perc. $\begin{array}{c}\text { Percentage } \\
\text { representation } \\
\text { of each group }\end{array}$ \\
\hline GROUP 0 & Parishes with no news & 990 & 57.2 & 57.2 & 57.2 \\
\hline GROUP 1 & More than 66 \% of news about conflicts & 186 & 10.7 & 25.1 & \\
\cline { 1 - 5 } GROUP 2 & $\begin{array}{l}\text { Between 33 \% and 66\% of news about } \\
\text { conflicts }\end{array}$ & 119 & 6.9 & 16.1 & \multirow{2}{*}{42.8} \\
\cline { 1 - 5 } GROUP 3 & Less than 33 \% of news about conflicts & 436 & 25.2 & 58.8 & \\
\hline Total & - & 1731 & 100 & 100 & 100 \\
\hline
\end{tabular}

Tab. 2 - Departure from normality of each variable in the hypothesis test after the Kolmogorov-Smirnov test. (STD): Standard deviation; (K-S Z): Z-values from the K-S test.

\begin{tabular}{llrrrr}
\hline Variable & Label & \multicolumn{1}{c}{ Mean } & \multicolumn{1}{c}{ STD } & K-S Z & Prob \\
\hline Population 2006 & $\mathrm{PO}_{2006}$ & 720.430 & 1301.314 & 7.949 & 0.000 \\
Population density (people/km ${ }^{2}$ ) & $\mathrm{PO}_{\mathrm{D}}$ & 1.403 & 6.885 & 11.423 & 0.000 \\
Owners engaged in agriculture (\%) & $\mathrm{OW}_{\mathrm{AG}}$ & 20.157 & 19.528 & 4.316 & 0.000 \\
Population aged 65 or more (\%) & $\mathrm{PO}_{65}$ & 30.295 & 11.331 & 2.106 & 0.000 \\
Non-woodland forest area (\%) & $\mathrm{NO}_{\text {WOOD }}$ & 11.098 & 16.653 & 6.875 & 0.000 \\
Forest area under fast-growing species (\%) & FO & 42.396 & 21.096 & 1.934 & 0.001 \\
Agricultural land area (\%) & $\mathrm{AG}$ & 35.859 & 16.870 & 1.102 & 0.177 \\
Forest area (\%) & $\mathrm{FO}$ & 59.199 & 19.557 & 1.965 & 0.001 \\
Forest area under slow-growing species (\%) & FO & 2.112 & 5.618 & 9.622 & 0.000 \\
Forest wood area (\%) & $\mathrm{FO}_{\text {WOOD }}$ & 44.500 & 20.212 & 2.059 & 0.000 \\
Evolution of population density 1960-2006 & $\mathrm{EV}_{1960-2006}$ & -0.260 & 0.543 & 3.697 & 0.000 \\
\hline
\end{tabular}

Tab. 3 - ANOVA results for each variable in the hypothesis test.

\begin{tabular}{|c|c|c|c|c|c|c|}
\hline Variable & Source of variation & Sum of squares & df & Mean Square & $\mathbf{F}$ & Prob \\
\hline \multirow{3}{*}{$\mathrm{PO}_{2006}$} & Between groups & 22366904.028 & 2 & 11183452.014 & 6.706 & 0.001 \\
\hline & Within groups & 1230763441.502 & 738 & 1667701.140 & - & - \\
\hline & Total & 1253130345.530 & 740 & - & - & - \\
\hline \multirow[t]{3}{*}{$\mathrm{PO}_{\mathrm{D}}$} & Between groups & 43.573 & 2 & 21.787 & 0.459 & 0.632 \\
\hline & Within groups & 35038.095 & 738 & 47.477 & - & - \\
\hline & Total & 35081.668 & 740 & - & - & - \\
\hline \multirow[t]{3}{*}{$\mathrm{OW}_{\mathrm{AG}}$} & Between groups & 7888.555 & 2 & 3944.277 & 10.611 & 0.000 \\
\hline & Within groups & 274317.342 & 738 & 371.704 & - & - \\
\hline & Total & 282205.897 & 740 & - & - & - \\
\hline \multirow[t]{3}{*}{$\mathrm{PO}_{65}$} & Between groups & 638.413 & 2 & 319.206 & 2.496 & 0.083 \\
\hline & Within $\mathrm{g}$ & 94365.579 & 738 & 127.867 & - & - \\
\hline & Total & 95003.992 & 740 & - & - & - \\
\hline \multirow[t]{3}{*}{$\mathrm{NO}_{\text {WOOD }}$} & Between groups & 5170.374 & 2 & 2585.187 & 9.537 & 0.000 \\
\hline & Within & 200053.743 & 738 & 271.076 & - & - \\
\hline & Total & 205224.117 & 740 & - & - & - \\
\hline \multirow[t]{3}{*}{ FO $_{\text {FAST }}$} & Between groups & 7271.629 & 2 & 3635.814 & 8.331 & 0.000 \\
\hline & Within $g$ & 322068.479 & 738 & 436.407 & - & - \\
\hline & Total & 329340.107 & 740 & - & _ & _ \\
\hline \multirow[t]{3}{*}{$\mathrm{AG}$} & Between groups & 1050.073 & 2 & 525.037 & 1.849 & 0.158 \\
\hline & Within groups & 209553.171 & 738 & 283.947 & - & - \\
\hline & Total & 210603.244 & 740 & - & - & - \\
\hline \multirow[t]{3}{*}{ FO } & Between groups & 4488.105 & 2 & 2244.053 & 5.946 & 0.003 \\
\hline & Within groups & 278540.335 & 738 & 377.426 & - & - \\
\hline & Total & 283028.440 & 740 & - & - & - \\
\hline \multirow[t]{3}{*}{$\mathrm{FO}_{\text {SLOW }}$} & Between groups & 523.479 & 2 & 261.739 & 8.460 & 0.000 \\
\hline & Within groups & 22832.849 & 738 & 30.939 & - & - \\
\hline & Total & 23356.328 & 740 & - & - & - \\
\hline \multirow[t]{3}{*}{$\mathrm{FO}_{\text {wOod }}$} & Between groups & 3954.357 & 2 & 1977.178 & 4.891 & 0.008 \\
\hline & Within groups & 298346.870 & 738 & 404.264 & - & - \\
\hline & Total & 302301.227 & 740 & - & - & - \\
\hline \multirow[t]{3}{*}{$\mathrm{EV}_{1960-2006}$} & Between groups & 1.585 & 2 & 0.792 & 2.695 & 0.068 \\
\hline & Within groups & 216.674 & 737 & 0.294 & - & - \\
\hline & Total & 218.259 & 739 & - & - & - \\
\hline
\end{tabular}


Tab. 4 - Results of the Scheffé's test for the comparison among group means of the variables showing significant differences after ANOVA.

\begin{tabular}{|c|c|c|c|c|c|}
\hline \multirow{2}{*}{$\begin{array}{l}\text { Type of } \\
\text { variable }\end{array}$} & \multirow{2}{*}{ Variable } & \multirow{2}{*}{ Group } & \multirow{2}{*}{$\mathbf{N}$} & \multicolumn{2}{|c|}{ Subgroups } \\
\hline & & & & 1 & 2 \\
\hline \multirow[t]{4}{*}{ Population } & $\mathrm{PO}_{2006}$ & GROUP 1 & 186 & 544.85 & - \\
\hline & & GROUP 2 & 119 & - & 1090.91 \\
\hline & & GROUP 3 & 436 & 694.22 & - \\
\hline & & Prob. & - & 0.536 & 1.000 \\
\hline \multirow{4}{*}{$\begin{array}{l}\text { Agricultural } \\
\text { activity }\end{array}$} & $\mathrm{OW}_{\mathrm{AG}}$ & GROUP 1 & 186 & - & 23.4892 \\
\hline & & GROUP 2 & 119 & 13.2202 & - \\
\hline & & GROUP 3 & 436 & - & 20.6287 \\
\hline & & Prob. & - & 1.000 & 0.359 \\
\hline \multirow{20}{*}{$\begin{array}{l}\text { Area and } \\
\text { land use }\end{array}$} & $\mathrm{NO}_{\text {WOOD }}$ & GROUP 1 & 186 & - & 14.9022 \\
\hline & & GROUP 2 & 119 & 13.0496 & 13.0496 \\
\hline & & GROUP 3 & 436 & 8.9427 & - \\
\hline & & Prob. & - & 0.055 & 0.554 \\
\hline & $\mathrm{FO}_{\mathrm{FAST}}$ & GROUP 1 & 186 & 37.9074 & - \\
\hline & & GROUP 2 & 119 & 40.0302 & 40.0302 \\
\hline & & GROUP 3 & 436 & - & 44.9564 \\
\hline & & Prob. & - & 0.618 & 0.075 \\
\hline & FO & GROUP 1 & 186 & - & 62.6720 \\
\hline & & GROUP 2 & 119 & 61.1765 & 61.1765 \\
\hline & & GROUP 3 & 436 & 57.1789 & - \\
\hline & & Prob. & - & 0.139 & 0.758 \\
\hline & $\mathrm{FO}_{\text {SLOW }}$ & GROUP 1 & 186 & - & 3.4406 \\
\hline & & GROUP 2 & 119 & 2.4166 & 2.4166 \\
\hline & & GROUP 3 & 436 & 1.4622 & - \\
\hline & & Prob. & - & 0.254 & 0.206 \\
\hline & $\mathrm{FO}_{\text {WOOD }}$ & GROUP 1 & 186 & 41.3481 & - \\
\hline & & GROUP 2 & 119 & 42.4467 & - \\
\hline & & GROUP 3 & 436 & 46.4186 & - \\
\hline & & Prob. & - & 0.052 & - \\
\hline
\end{tabular}

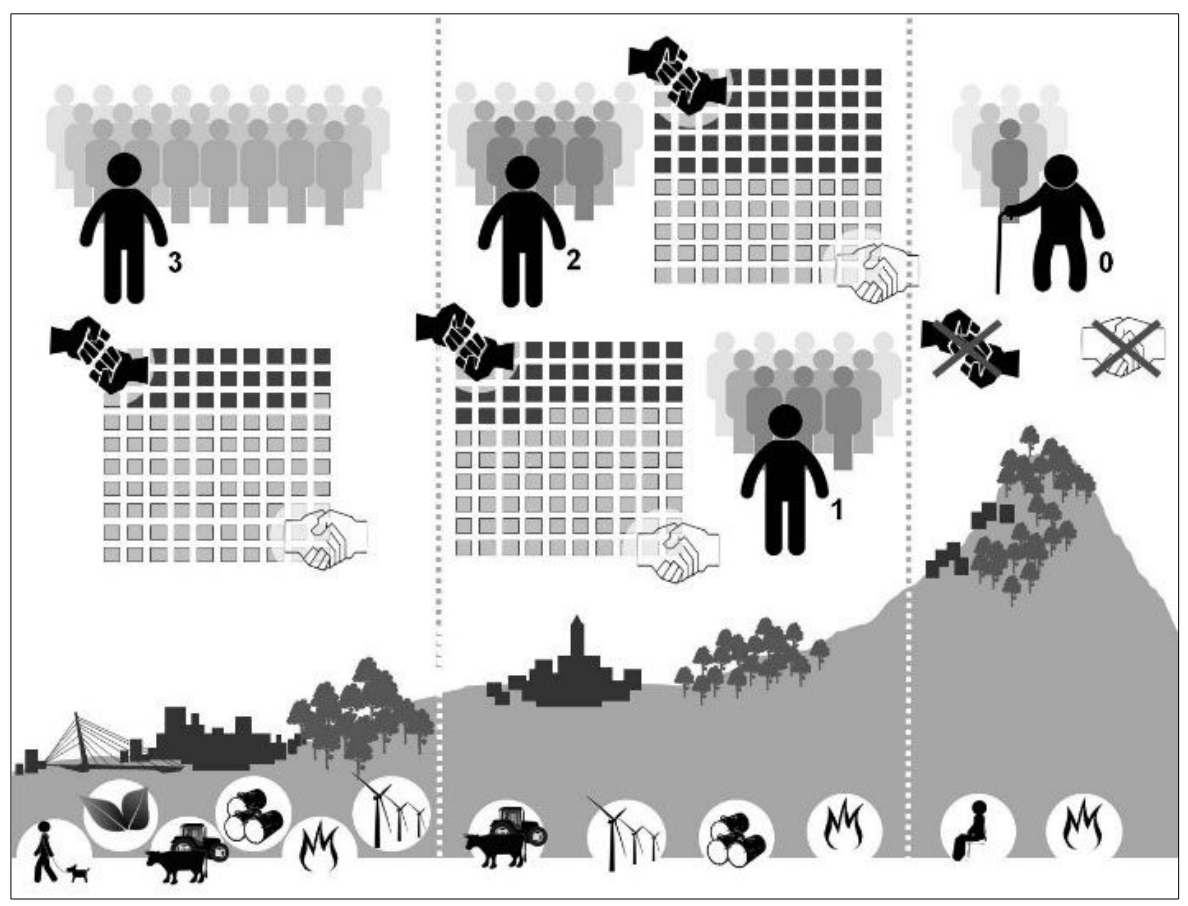

Fig. 6 - Schematic representation of the characteristics of the areas (activities, territory, population and conflicts) for the three parish groups identified in this study. important to know the opinion of society concerning the management of common resources. Other authors (Ohkura 2003, Hovardas \& Korfiatis 2008) also showed the importance of taking into account society's opinion for the improvement of management efficiency.

Of the 1731 parishes with MVMC included in this study, $57.2 \%$ showed a passive attitude towards the management of their lands (no news items recorded). Schlueter (2008) defined passivity or apathy as a lack of interest in the management of these resources. There are historical reasons for this. Several authors reported as the main reason for this passivity the unstable legal process regarding the ownership of common lands throughout the $20^{\text {th }}$ century (Balboa López et al. 2006, Marey-Pérez et al. 2006, 2010, Marey-Pérez \& Rodríguez-Vicente 2008). MVMC have undergone changes in ownership, going from private to public, and then from public to collectively-owned private lands, which is their current legal status (DOG 1989). Another factor that may explain this lack of interest is the decline of the traditional agricultural model of the region (Fandiño et al. 2006, Riveiro et al. 2007). Such decline has meant that the number of commercially-run farms has been drastically reduced to only $15 \%$ of those existing in the middle of the $20^{\text {th }}$ century. Linked to this decline in farms has been a decrease in the financial gains from MVMC (González et al. 2007). The third factor is the decline in rural population levels (Pinto-Correia 2000). At the beginning of the 21th century, the rural population was one-quarter of what it was a century before. It may be hypothesized that the main arguments justifying the extreme lack of interest in such properties throughout most of the region are legal insecurity regarding land tenancy, lack of demand for the natural resources provided by MVMC, and lack of people with interest and ability to manage the land.

These lands were returned to the residents of the parishes as commonly-owned lands over the last three decades of the $20^{\text {th }}$ century. Mattson et al. (1996) highlighted the importance of training the owners of natural resources in land management. Others demonstrated that major conflicts can arise if land is not properly managed (Skutsch 2000, Hellström 2001). Gómez-Vázquez et al. (2009) reported about the extent of conflicts over commonly-owned lands in this area. It is also worth to notice that when these lands were returned, landowners and managers were not properly trained and there was no land management organization, which caused conflicts and overexploitation (Dietz et al. 2003, Ostrom 2005). Lack of management experience, the absence of connections between the different communities, and historical land disputes were common causes of 
increased conflict over these lands in different areas (Aasetre 2006, Matta \& Alavalapati 2006). As demonstrated by Hovardas \& Korfiatis (2008), lack of clarity about rights and obligations, both within the community of owners itself and between the community and other neighboring communities, results in increased conflict in the area of management. Ostrom (2010) pointed out that "in order to effectively govern and manage a common-pool resources some form of propertyrights system must be developed".

Fig. 6 presents a schematic of the distribution in Galicia of the different groups obtained and the characteristics of the areas they represent. The largest group generated less than $33 \%$ of the news items related to conflict (GROUP 3), and it consisted of 436 parishes, represented by $25.2 \%$ of all parishes with MVMC. In this group, geographically located in coastal areas, management was of greater importance. The demographic process in these areas was the opposite of that throughout the rest of the region as there was a major increase in the number of inhabitants and variation in the characteristics of the population. The profile varied from rural to rural/urban (Barros 1999), the primary sector used to be the economic driving force, but now the secondary and tertiary sectors fulfill this role. These changes have meant that the demands of the new societies who own the mountain land are very different from those of the farmers and stock holders who used to own them, as highlighted by Gómez-Vázquez et al. (2009). The new owners and managers, who have no links to primary activities of this type, demand that the common areas provide services related to the enjoyment of nature. The results obtained for this group show that, while there is a certain amount of conflict related to the existence of different socioeconomic groups, a management model that responds to the demands of community members for goods and services results in the use of land for different types of activities. As started by Steins \& Edwards (1999), when an important social, institutional or territorial change takes place in common resources, "the institutional framework governing resource use has to be re-negotiated to avoid adverse impacts associated with the increased access of any new stakeholders, such as overexploitation, alienation of traditional users, and inter-user conflicts". Second, it seems that common lands are playing an important role in the socioeconomic development of these areas (Pagdee et al. 2006, Maskey et al. 2006). Their level of involvement in the rules regarding land use is going to be related to their willingness to follow and supervise their implementation, which is going to be much higher than when imposed by authorities (Ostrom \& Nagendra 2006).

GROUP 1 was the second-largest group

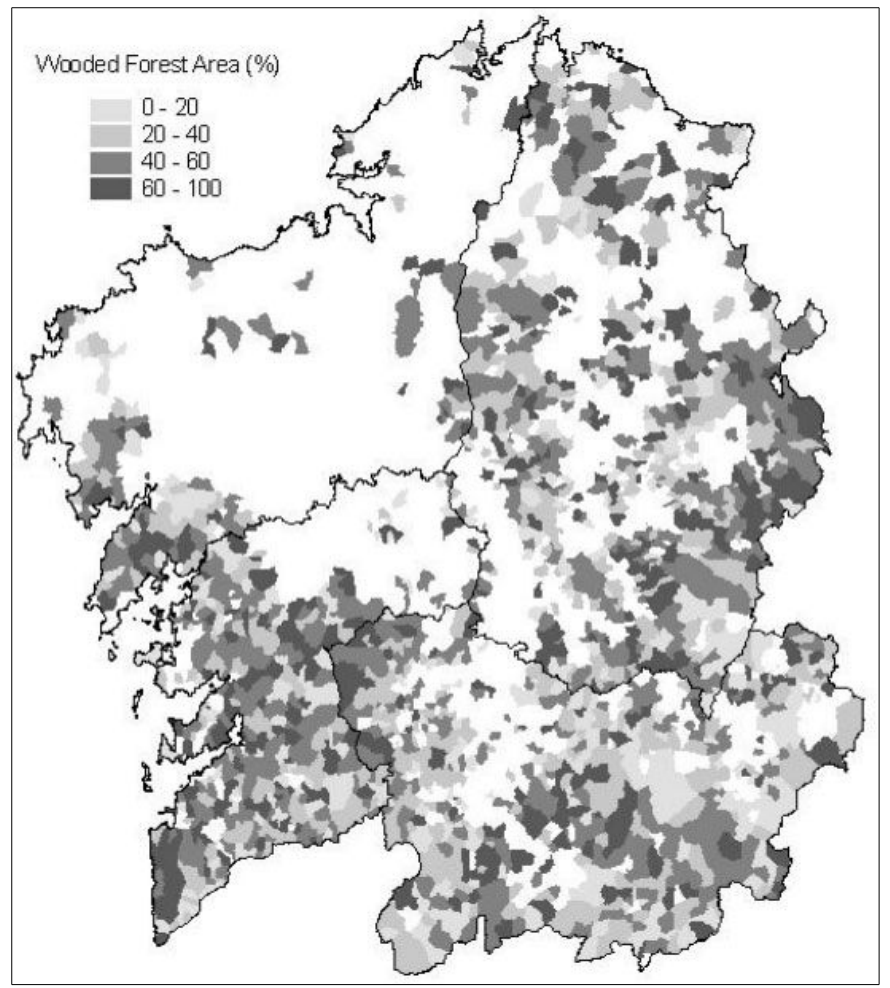

Fig. 7 - Geographical distribution of forest lands (Wooded Forest Area, \%) in Galicia.

and included parishes where over two-thirds of the news items were about situations of conflict. In these parishes, inland areas of the region of valleys and mountains, livestock farms are active but the population is declining and growing old. The most reasonable explanation for this is that the new uses for the land (mainly as a source of energy) spark financial interest, together with the traditional wish for the division of land into individual parcels (Marey-Pérez \& RodríguezVicente 2008). This in turn is the root cause of much conflict (Skutsch 2000), either within the community (Brehm 2007), with institutions (Ibarra \& Hirakuri 2007) or with energy companies (De Jong et al. 2006). As such, adjusting to a new socioeconomic situation has led to significant changes in land use and in traditional management practices within an unstable legal, financial and demographic framework (Hoogstra et al. 2004, Ziegenspeck et al. 2004, Pardo \& Gil 2005, Salka et al. 2006).

GROUP 2 was the third largest group, and showed a balance between the news items reported due to management, and those due to conflict. This group shared some aspects of the two previous cases. The first remarkable aspect was certain changes in the population that resulted in active management, which was often increased with the emergence of new sources of finance. For example, the use of renewable energy, teamed with conflicts regarding the management model applied (Gobin et al. 2001). The second aspect is that conflict is still a relevant issue in management participation, but with a smaller degree of representation of the total number of parishes about which news items were published.

The results reported in Tab. 1 and those of the Fig. 3, Fig. 4, Fig. 5 and Fig. 6, suggest that there are two main types of MVMC distributed across two geographical areas of Galicia with different social, cultural and economic realities. The evolution of population is the key in such a differentiation (Owen et al. 2000), and the trends of population loss or growth since the 1950s are at the origin of this behavior. The population growth in some areas (e.g., those corresponding with GROUP 3) has increased the number of newcomers to rural areas, who introduced new criteria for land management: they automatically acquired the right to manage the forest, but their opinion on what to do and how can differ from formerly established trends. For instance, newly demanded uses like leisure activities, biodiversity protection, energy production (e.g., windfarms and solar panels), food production linked to forest (e.g., mushrooms, berries and agroforestry) or the adoption of new technologies and methods for agriculture and forestry production may spatially concur in the same forest thus requiring more complex ways of management. Conversely, in other areas the loss of population generates a complete lack of interest (Montiel Molina 2007).

There were seven variables related to population, agriculture and land use that influence any differences between the various types of parishes (Tab. 4), leading to a more detailed explanation of the relationship be- 
tween conflict and management. For the population in 2006, the number of inhabitants seemed to influence the relationship between conflicts and management (Siiskonen 2007). This affects both the level of demand for goods and services and the management models of commonly-owned land, which leads to situations of conflict (Van Der Ploeg \& Roep 2003). Groups of parishes with more inhabitants can give rise either to situations of extreme or low levels of conflict. In areas where agricultural activity is more prevalent, it is linked to a higher demand for resources and so to greater levels of conflict (Djamhuri 2008), for instance due to grazing (Rohde et al. 2006). Marey-Pérez et al. $(2006,2010)$ pointed out that the continuation of agricultural activity in MVMC is linked to more active management models, which promote the existence of stable models with a lesser degree of conflict.

The distribution of wooded forest area in each parish analyzed as percentages (Fig. 7) shows the importance of the use of these lands for forestry purposes. An increase in the area of forest land without trees is a symptom of lack of management and of a higher number of conflicts that is clearly manifest in repeated forest fires (Chas Amil 2007, Gómez-Vázquez et al. 2009). This results in vegetation consisting of scrub (Mermoz et al. 2005, Pardo \& Gil 2005). Severa authors found that the main causes of forest fires are socioeconomic in nature (Vázquez \& Moreno 2001, Lloret et al. 2002). MareyPérez \& Rodríguez-Vicente (2008) included conflicts resulting from communal management and ownership as the main causes in this region. If the situation were reversed, there would be areas of wooded forest area, which is a clear indicator of no recent forest fires (Nunes et al. 2005).

In areas where the topographical conditions and forest productivity allow for an increase in fast-growing cash crops, the communities that own the land experience a lesser degree of conflict, because income is received sooner, resulting in improved management (Montiel Molina 2007). By contrast, in other areas where forest productivity conditions have made it necessary to resort to slower-growing species, management models to resolve conflicts have been created, which has made it possible to maintain forestry activities.

\section{Conclusions}

Digital records of local and regional media have been shown to provide an opportunity to discover the opinions of society reasonably quickly and inexpensively, thus making it possible to analyze and diagnose territorial management problems. Collectivelyowned private property has been shown to play an important role in the development of the economy of this region. The methodo- logy presented, based on the compilation, analysis and representation of social opinions about activity in common lands, has made it possible to evaluate the different management models used by the owners of these lands. Different authors (Ziegenspeck et al. 2004, Hoogstra et al. 2004, Olsson et al. 2004, Atmis et al. 2007, Brehm 2007, Kumar et al. 2009) have analyzed the social changes and how they have influenced the management models of collective private forest land.

Results showed the existence of different spatial distribution of the relationship between management and conflict, taking into account their different origins and causes. This variability has been caused by demographic trends and lack of training in management models for this type of property. The most active group of parishes is characterized by a high number of management proposals and a low level of conflict, and this is reflected in the presence of wooded forest area. The parishes with a high number of conflicts have no planned management models and do not use the land for any purpose, with the result that forest areas are covered with scrub.

This project has emphasized rural depopulation as the main problem affecting Galicia. The availability of MVMC provides an opportunity for development and promotion of economic activities linked to the forestry sector that can slow down the decline in population.

Over the past 40 years, the implementation of an efficient management model in the whole territory has failed, as demonstrated by the large number of communities lacking any form of management activity over time. This unsustainable development of forestry is a loss of opportunities in many parishes. Another significant group of parishes has tried to develop models and mechanisms for the land management. However, due to the lack of training and of reference models, and as a result of disputes both within and between parishes, it has been impossible to implement productive activities, leading ultimately to increased abandonment.

Even if in the case of Galicia we are dealing with under-exploitation, it will be necessary to consider in the future that overharvesting of natural resources is a time-consuming and difficult task (Ostrom \& Nagendra 2006), since it needs "to fit a local ecology and the social structure of the users and officials involved and to avoid crowding out intrinsic motivation". Mechanisms to resolve conflicts and to encourage owners of communities to set up management models based on sustainable forestry development, have to be implemented in a short time by local policymakers.

In this way, balanced sustainable rural forestry development will help to maintain forest activity in a region with an agricultural history of more than 2000 years.

\section{Acknowledgements}

We are grateful to the Galician Government, Xunta de Galicia, Dirección Xeral de Investigación, Desenvolvemento e Innovación, Xunta de Galicia, for funding the project "A decision support system for montes veciñais en man común (DSSMVMC)" (07MRU035291PR).

\section{References}

Aasetre J (2006). Perceptions of communication in Norwegian forest management. Forest Policy and Economics 8: 81-92. - doi: 10.1016/j.forpol.2004.06.001

AIMC (2009). Estudio General de Medios (EGM) [General Media Survey (EGM)]. AIMC - Asociación para la Investigación de Medios de Comunicación, Madrid, Spain, pp. 14. [in Spanish] Alberich T (2002). Participación ciudadana [Citizen participation]. In: "Diccionario critico de Ciencias Sociales" (Reyes R ed). [online] URL: http://pendientedemigracion.ucm.es/info/eurothe $\mathrm{o} /$ diccionario/P/

Atmis E, Özden S, Lise W (2007). Public participation in forestry in Turkey. Ecological Economics 62: 352-359. - doi: 10.1016/j.ecolecon. 20 06.07.002

Balboa López X, Besteiro Rodríguez B, Fernández Leiceaga $X$, Fernández Prieto L, Jordán Rodríguez M, López Iglesias E, Soto Fernández D, Viso Outeiriño P (2006). Os Montes Veciñais en man Común: o patrimonio silente. Natureza, economía, identidade e democracia na Galicia rural [The Communal forests: a silent heritage. Nature, economy, identity and democracy in rural Galicia]. Edicións Xerais de Galicia, Vigo, Spain, pp. 520. [in Galician]

Barli O, Baskent EZ, Turker MF, Gedik T (2006). Analytical approach for analyzing and providing solutions for the conflicts among forest stakeholders across Turkey. Forest Policy and Economics 9: 219-236. - doi: 10.1016/j.forpol.2005. 07.009

Barros C (1999). De rural a rururbano: transformaciones territoriales y construcción de lugares al sudoeste del área metropolitana de Buenos Aires [From rural to rururban: territorial transformations and construction of places to the southwest of the metropolitan area of Buenos Aires] Revista Electrónica de Geografía y Ciencias Sociales 45: 51-53. [in Spanish]

Bengston DN, Fan DP (1999). Conflict over natural resource management: a social indicator based on analysis of online news media text. Society and Natural Resources 12: 493-500. - doi: 10.1080/089419299279560

Bogale A, Taeb M, Endo M (2006). Land ownership and conflicts over the use of resources: implication for household vulnerability in eastern Ethiopia. Ecological Economics 58: 134-145. doi: 10.1016/j.ecolecon.2005.07.002

Bouhier MA (1979). La Galice. Essai géographique d'analyse et d'interpretation d'un 
vieux complexe agraire [Galicia. Proof of geographic analysis and interpretation of an old agricultural complex]. La Roche-sur-Yon, Imp. Yonnaise, Poitiers, France, pp. 1526. [in French] Bojórquez-Tapia LA, De la Cueva H, Díaz S, Melgarejo D, Alcantar G, Solares MJ, Grobet G, Cruz-Bello G (2004). Environmental conflicts and nature reserves: redesigning Sierra San Pedro Mártir National Park, México. Biological Conservation 117: 111-126. - doi: 10.1016/S00 06-3207(03)00265-9

Brehm J (2007). Community attachment: the complexity and consequence of the natural environment facet. Human Ecology 35: 477-488. - doi: 10.1007/s10745-006-9104-3

Brett M (2005). An economic theory of infrastructure and commons management. Minnesota Law Review 89: 917-1030.

Cantiani MG (2012). Forest planning and public participation: a possible methodological approach. iForest 5:72-82. - doi: 10.3832/ifor0602009

Carver A, Thurau R, White E, Laznidis M (2006). Applying spatial analysis to forest policy evaluation: case study of the Illinois Forestry Development Act. Environmental Science and Policy 9: 253-260. - doi: 10.1016/j.envsci.2006.01.002

Chambers JM, Trevor J (1992). Statistical Models in S. Chapman and Hall, New York, USA, pp. 624.

Chas Amil M (2007). Forest fires in Galicia (Spain): threats and challenges for the future. Journal of Forest Economics 13: 1-5. - doi: 10.1016/j.jfe.2007.02.001

De Jong W, Ruiz S, Becker M (2006). Conflicts and communal forest management in northern Bolivia. Forest Policy and Economics 8: $447-$ 457. - doi: 10.1016/j.forpol.2005.08.011

De Moor T, Bravo G (2008). The commons in Europe: from past to future. International Journal of the Commos 2 (2): 155-161.

Díaz Fuentes A (1999). Montes Vecinales en Mano Común [Communal forests]. Bosch, Barcelona, Spain, pp. 386. [in Spanish]

Dietz T, Ostrom E, Stern P (2003). The struggle to govern the commons. Science 302 (5652): 1907 1912. - doi: $10.1126 /$ science. 1091015

Djamhuri TL (2008). Community participation in a social forestry program in Central Java, Indonesia: the effect of incentive structure and social capital. Agroforest System 74: 83-96. - doi: 10.1007/s10457-008-9150-5

DOG (1989). Lei 13/1989 do 10 de outubro de Montes Veciñais en Man Común [Law no13 of 1989 of 10 October of Communal Forests]. Diario Oficial de Galicia no. 202, Xunta de Galicia, Santiago de Compostela, Spain, pp. 15. [in Galician]

Druckman D (2005). Doing research. Methods of inquiry for conflict analysis. SAGE Publications Inc., London, UK, pp. 387.

Elands HM, Oleary T, Boerwinkel H, Wiersum F (2004). Forests as a mirror of rural conditions: local views on the role of forests across Europe. Forest Policy and Economics 5: 469-482. - doi: 10.1016/j.forpol.2004.01.003
Elsasser P (2002). Rules for participation and negotiation and their possible influence on the content of a national forest program. Forest Policy and Economics 4: 291-300. - doi: 10.1016/S13 89-9341(02)00071-0

Fandiño M, Álvarez C, Ramos R, Marey MF (2006). Agricultural cooperatives as transforming agents in rural development. The case of Galicia. Outlook on Agriculture 35 (2): 191-197. - doi: 10.5367/000000006778536710

Fernandes PM (2008). Forest fires in Galicia (Spain): the outcome of unbalanced fire management. Journal of Forest Economics 14: 155-157. - doi: 10.1016/j.jfe.2007.11.002

Fernández S, Marey MF, Crecente R, Rodríguez $\mathrm{V}$ (2006). Is having a specific legal framework the only way for improving nowadays the management of communal lands? An analysis of the "Montes Veciñais en Man Común in Galicia NW Spain". In: Proceedings of the "European Meeting of the International Association for the study of Common Property". Brescia (Italy) 23-25 March 2006, pp. 1-16.

Glück P (2000). Policy means for ensuring the full value of forests to society. Land Use Policy 17 : 177-185. - doi: 10.1016/S0264-8377(00)000181

Gobin A, Campling P, Feyen J (2001). Logistic modelling to identify and monitor local land management systems. Agricultural Systems 67 (1): 1-20. - doi: 10.1016/S0308-521X(00)000433

Gómez-Vázquez I, Álvarez-Álvarez P, Marey-Pérez MF (2009). Conflicts as enhancers or barriers to the management of privately owned common land: A method to analyse the role of conflicts on a regional basis. Forest Policy and Economics 11: 617-627. - doi: 10.1016/j.forpol.2009.09.001 González XP, Marey MF, Alvarez CJ (2007). Evaluation of productive rural land patterns with joint regard to the size, shape and dispersion of plots. Agricultural Systems 92: 52-62. - doi: 10.1016/j.agsy.2006.02.008

Gritten D, Saastamoinen O, Sajama S (2009). Ethical analysis: a structured approach to facilitate the resolution of forest conflicts. Forest Policy and Economics 11 (8): 555-560. - doi: 10.10 16/j.forpol.2009.07.003

Groome H (1990). Historia de la Política Forestal en el Estado español [History of forest policy in the Spanish State]. Agencia del Medio Ambiente, Madrid, Spain, pp. 336.

GvSIG (2010). SIG libre de la Generalitat Valenciana [Free GIS of Valencian Government]. Web Site. [in Spanish]. [online] URL: http://www. gvsig.org/web/

Hellström E (2001). Conflict cultures-qualitative comparative analysis of environmental conflicts in forestry. Silva Fennica Monographs 2, The Finnish Society of Forest Science, The Finnish Research Institute, Tampere, Finland, pp. 109.

Hickey GM, Innes JL, Kozak RA (2007). Monitoring and information reporting for sustainable forest management: A regional comparison of forestry stakeholder perceptions. Journal of Environmental Management 84 (4): 572-585. - doi: 10.1016/j.jenvman.2006.07.004

Hiltunen V, Kurttila M, Leskinen P, Pasanen K, Pykäläinen J (2009). Mesta: an internet-based decision-support application for participatory strategic-level natural resources planning. Forest Policy and Economics 11: 1-9. - doi: 10.1016/j.forpol.2008.07.004

Hoogstra MA, Schanz H, Wiersum KF (2004). The future of European forestry-between urbanization and rural development. Forest Policy and Economics 6: 441-445. - doi: 10.1016/j.forpol.2 004.01.001

Hovardas T, Korfiatis KJ (2008). Framing environmental policy by the local press: case study from the Dadia Forest Reserve, Greece. Forest Policy and Economics 10: 316-325. - doi: 10.10 16/j.forpol.2007.12.001

Ibarra E, Hirakuri SR (2007). Institutional conflict and forest policy effectiveness: the case of the Costa Rican institutional reform. Forest Policy and Economics 9: 591-601. - doi: 10.1016/j.forpol.2005.12.002

ILO (2000). Public participation in forestry in Europe and North America: report of the team of specialists on participation in forestry. Report of the FAO/ECE/ILO Joint committee team of specialists on participation in forestry, WP 163 , International Labour Office, Geneva, Switzerland, pp. 130.

INE (2008). Padrón Municipal de Habitantes [Municipal Register of people]. Instituto Nacional de Estadística, Madrid, Spain. [in Spanish] [online] URL: http://www.ine.es/inebmenu/mn u_padron

Janse G, Konijnendijk C (2007). Communication between science, policy and citizens in public participation in urban forestry - experiences from the Neighbourwoods project. Urban Forestry and Urban Greening 6: 23-40. - doi: 10.1016/j.ufug. 2006.09.005

Kangas J, Store R (2003). Internet and teledemocracy in participatory planning of natural resources management. Landscape and Urban Planning 62: 89-101. - doi: 10.1016/S0169-2046(02)0012 5-1

Kangas A, Saarinen N, Saarikoski H, Leskinen LA, Hujala T, Tikkanen J (2010). Stakeholder perspectives about proper participation for $\mathrm{Re}$ gional Forest Programmes in Finland. Forest Policy and Economics 12: 213-222. - doi: 10.1016/ j.forpol.2009.10.006

Kumar P, Hate S, Chaturvedi A (2009). Community based forest management and its impact on vegetation: a case study. iForest 2: 93-98. - doi: 10.3832/ifor0490-002

Leiceaga X, López E, Jordán M, Besteiro B, Viso P, Balboa XL, Fernández L, Soto D (2006). OsMontes Veciñais en Man Común: o patrimonio silente [The Communal forests: a silent heritage]. Grupo de Estudios da propiedade ComunalIDEGA, Edicións Xerais de Galicia, Santiago de Compostela, Spain, pp. 325.

Lennox J, Proctor W, Russell S (2011). Structuring stakeholder participation in New Zealand's water resource governance. Ecological Economics 70: 1381-1394. - doi: 10.1016/j.ecolecon. 
2011.02.015

Lloret F, Calvo E, Pons X, Díaz-Delgado R (2002). Wildfires and landscape patterns in the Eastern Iberian Peninsula. Landscape Ecology 17: 745-759. - doi: 10.1023/A:1022966930861 Marey-Pérez MF (2003). Tenencia de la tierra en Galicia: modelo para la caracterización de los propietarios forestales [Land tenure in Galicia: a model for the characterization of forest owners]. Doctoral Thesis, Universidade de Santiago de Compostela, Spain, pp. 633.

Marey-Pérez MF, Rodríguez-Vicente V, Crecente Maseda R (2006). Using GIS to measure changes in the temporal and spatial dynamics of forestland: experiences from north-west Spain. Forestry 79 (4): 409-423. - doi: 10.1093/forestry/ cpl027

Marey-Pérez MF, Rodríguez-Vicente V (2008). Forest transition in Northern Spain: local responses on large-scale programmes of field-afforestation. Land Use Policy 261: 139-156.

Marey-Pérez MF, Gómez-Vázquez I, Díaz-Varela ER (2010). Different approaches to the social vision of communal land management: The case of Galicia (Spain). Spanish Journal of Agricultural Research 3: 848-863. - doi: 10.5424/sjar/2010 083-1287

Maskey V, Gebremedhin TG, Dalton TJ (2006). Social and cultural determinants of collective management of community forest in Nepal. Journal of Forest Economics 11: 261-274. - doi: 10.1016/j.jfe.2005.10.004

Matta JR, Alavalapati JRR (2006). Perceptions of collective action and its success in community based natural resource management: an empirical analysis. Forest Policy and Economic 9: 274284. - doi: 10.1016/j.forpol.2005.06.014

Mattson DJ, Hererro S, Wright RG, Pease CM (1996). Science and management of Rocky Mountain grizzly bears. Conservation Biology 10:1013-1025. - doi: 10.1046/j.1523-1739.1996. 10041013.x

McCallum DB, Hammond SL, Covello VT (1991). Communicating about environmental risks: how the public uses and perceives information sources. Health Education Quarterly 18: 349-361. - doi: 10.1177/109019819101800307

Mei Szen MN, Sovacool BK (2013). Of fast lanes, flora, and foreign workers: managing land use conflicts in Singapore. Land Use Policy 30: $167-$ 176.

Meitner MJ, Ryan Gandy R, D'Eon RG (2005). Human perceptions of forest fragmentation: implications for natural disturbance management. The Forestry Chronicle 81: 258-264. - doi: $10.5558 / \mathrm{tfc} 81256-2$

Merlo M (1995). Common property forest management in Northern Italy: a historical and socioeconomic profile. Unasylva 180 (46): 58-63.

Mermoz M, Kitzberger T, Veblen TT (2005). Landscape influences on occurrence and spread of wildfires in Patagonian forests and shrublands. Ecology 86: 2705-2715. - doi: 10.1890/ 04-1850

Miserendino ML, Masi CI (2010). The effects of land use on environmental features and func- tional organization of macroinvertebrate communities in Patagonian low order streams. Ecological Indicators 10 (2): 311-319. - doi: 10.1016/ j.ecolind.2009.06.008

Montiel Molina C (2007). Cultural heritage, sustainable forest management and property in inland Spain. Forest Ecology and Management 249: 80-90. - doi: 10.1016/j.foreco.2007.05.031

Niemelä J, Young J, Alard D, Askasivar M, Henle K, Jhonson R, Kurttila M, Larsson T, Matouch S, Nowick P, Paiva R, Portoghesi L, Smulders R, Stevenson A, Tartes U, Watt A (2005). Identifying, managing and monitoring conflicts between forest biodiversity conservation and other human interests in Europe. Forest Policy and Economics 7: 877-890. - doi: 10.1016/j.forpol.2004.04.005 Niskanen A, Lin C (2001). Regional similarities of forest resources and socio-economic structures in the EU member states. Forest Policy and Economics 3: 55-67. - doi: 10.1016/S1389-9341(01) 00041-7

Nunes MCS, Vasconcelos MJ, Pereira JMC, Dasgupta N, Alldredge RJ, Rego FC (2005). Land cover type and fire in Portugal: do fires burn land cover selectively? Landscape Ecology 20: 661-673. - doi: 10.1007/s10980-005-0070-8

Ohkura Y (2003). The roles and limitations of newspapers in environmental reporting. Case study: Isahaya Bay land reclamation project issue. Marine Pollution Bulletin 47: 237-245. doi: 10.1016/S0025-326X(03)00057-2

Olsson P, Folke C, Berkes F (2004). Adaptive comanagement for building resilience in socialecological systems. Environmental Management 34 (1): 75-90. - doi: 10.1007/s00267-003-0101-7 O'Leary TN, McCormack AG, Clinch JP (2000). Afforestation in Ireland: regional differences in attitude. Land Use Policy 17: 39-48. - doi: 10.10 16/S0264-8377(99)00036-8

Ostrom E (2005). Understanding institutional diversity. Princeton University Press, Princeton, NJ, USA, pp. 376.

Ostrom E, Nagendra H (2006). Insights on linking forests, trees, and people from the air, on the ground, and in the laboratory. Proceedings of the National Academy of Sciences USA 103: 1922419231. - doi: 10.1073/pnas.0607962103

Ostrom E (2010). Analyzing collective action. Agricultural Economics 41: 155-166. - doi: 10.1111/j.1574-0862.2010.00497.x

Owen L, Howard W, Waldron M (2000). Conflicts over farming practises in Canada: the role of interactive conflicts resolution approaches. Journal of Rural Studies 16: 475-483. - doi: 10.1016/S0743-0167(00)00023-1

Pagdee A, Kim YS, Daugherty PJ (2006). What makes community forest management successful: a meta-study from community forests throughout the world. Society and natural resources 19 (1): 33-52. - doi: 10.1080/08941920500 323260

Pardo F, Gil L (2005). The impact of traditional land use on woodlands: a case study in the Spanish Central System. Historical Geography 31: 390-408. - doi: 10.1016/j.jhg.2004.11.002

Pinto-Correia T (2000). Future development in
Portuguese rural areas: how to manage agricultural support for landscape conservation? Landscape and Urban Planning 50: 95-106. - doi: 10.1016/S0169-2046(00)00082-7

Penker M (2009). Landscape governance for or by the local population? A property rights analysis in Austria. Land Use Policy 26: 947-953. - doi: 10.1016/j.landusepol.2008.11.007

Prada A, González M, Polomé P, González XM, Vázquez MX (2001). Valoración económica del patrimonio natural [Economic valuation of natural heritage]. Fundacion Pedro Barrie de la Maza-Banco Pastor, A Coruna, Spain, pp. 243. [in Spanish]

R Development Core Team (2008). R: a language and environment for statistical computing. R Foundation for Statistical Computing, Vienna, Austria. [online] URL: http://www.r-project.org/ Reed MG (2007). Uneven environmental management: a Canadian perspective. Environmental Management 39: 30-49. - doi: 10.1007/s00267005-0159-5

Rice JA (1995). Mathematical statistics and data analysis $\left(2^{\text {nd }} \mathrm{edn}\right)$. Duxbury Press, Belmont, CA, USA, pp. 602.

Riveiro JM, Marey-Pérez MF, Marco JL, Alvarez CJ (2007). Procedure for the classification and characterization of farms for agricultural production planning: application in the northwest of Spain. Computers and Electronics in Agriculture 61: 169-178. - doi: 10.1016/j.compag.2007.11. 003

Rohde RF, Moleele NM, Mphale M, Allsopp N, Chanda R, Hoffman MT (2006). Dynamics of grazing policy and practice: environmental and social impacts in three communal areas of southern Africa. Environmental Science and Policy 9: 302-316. - doi: 10.1016/j.envsci.2005.11.009 Salka J, Longauer R, Lacko M (2006). The effects of property transformation on forestry entrepreneurship and innovation in the context of Slovakia. Forest Policy and Economics 8: 716-724. - doi: 10.1016/j.forpol.2005.06.017

Santos R, Antunes P, Baptista G, Mateus P, Madruga L (2006). Stakeholder participation in the design of environmental policy mixes. Ecological Economics 60: 100-110. - doi: 10.1016/j. ecolecon.2005.11.025

Schlueter A (2008). Small-scale European forestry, an anticommons? International Journal of the Commons 2 (2): 248-268. [online] URL: http://www.thecommonsjournal.org/index.php/ij c/article/viewArticle/42

Short C (2000). Common land and ELMS: a need for policy innovation in England and Wales. Land Use Policy 17: 121-133. - doi: 10.1016/ S0264-8377(00)00007-7

Siiskonen H (2007). The conflict between traditional and scientific forest management in $20^{\text {th }}$ century Finland. Forest Ecology and Management 249: 125-133. - doi: 10.1016/j.foreco.20 07.03.018

Skutsch MM (2000). Conflict management and participation in community Forestry. Agroforestry Systems 48: 189-206. - doi: 10.1023/ A:1006328403023 
Soliño M (2003). Programas forestales en las comunidades de montes vecinales en mano común en la Red Natura 2000: Un análisis delphi [Forest programs in the communities of communal forests mountains in Natura 2000: A Delphi analysis]. Revista Galega de Economía 12: 1-22. [in Spanish]

Steins NA, Edwards VM (1999). Platforms for collective action in multiple-use common-pool resources. Agriculture and Human Values 16: 241-255. - doi: 10.1023/A:1007591401621

Susskind L, Cruikshank J (1987). Breaking the impasses: consensual approaches to resolving public disputes. Basic books, New York, NY, USA, pp. 276.

Van Der Ploeg JD, Roep D (2003). Multifunctionality and rural development: the actual situation in Europe. In: "Multifunctional Agriculture. A New Paradigm for European Agriculture and Rural Development" (Van Huylenbroeck G, Durand
G eds). Ashgate, Aldershot, New Hampshire, UK, pp. 37-53.

Vázquez A, Moreno JM (2001). Spatial distribution of forest fires in Sierra de Gredos (Central Spain). Forest Ecology and Management 147: 55-65. - doi: 10.1016/S0378-1127(00)00436-9

Wakefield SEL, Elliott SL (2003). Constructing the news: the role of local newspapers in environmental risk communication. The Professional Geographer 55: 216-226. [online] URL: http:// www.tandfonline.com/doi/abs/10.1111/0033-01 24.5502009

Wallgren M, Skarpe C, Bergstrom R, Danell K, Bergstrom A, Jakobsson T, Karlsson K, Strand T (2009). Influence of land use on the abundance of wildlife and livestock in the Kalahari, Botswana. Journal of Arid Environments 73 (3): 314-321. - doi: 10.1016/j.jaridenv.2008.09.019

White M, Fischer A, Marshall K, Travis MJ, Webb J, Di Falco S, Redpath M, Van der Walf R
(2009). Developing an integrated conceptual framework to understand biodiversity conflicts. Land Use Policy 26: 242-253. - doi: 10.1016/j.landusepol.2008.03.005

Xu Z, Bengston DM (1997). Trends in national forest values among forestry professionals, environmentalists, and the news media, 1982-1993. Society and Natural Resources 10: 43-59. - doi: 10.1080/08941929709381008

Yasmi Y, Schanz H, Salim A (2006). Manifestation of conflict escalation in natural resource management. Environmental Science and Policy 9: 538-546. - doi: 10.1016/j.envsci.2006.04.003

Ziegenspeck S, Härter U, Schraml U (2004). Lifestyles of private forest owners as an indication of social change. Forest Policy and Economics 6 (5): 447-458. - doi: 10.1016/j.forpol.2004.01. 004 